\title{
A STUDY ON CUTANEOUS ADVERSE DRUG REACTIONS REPORTED IN A TERTIARY CARE HOSPITAL, KANCHIPURAM
}

\author{
NITHYA PANNEERSELVAM*, PARIMALA KADHIRVELU, REVATHI SOMASUNDARAM, \\ SOUNDARRAJAN JAYAPRAKASH
}

\begin{abstract}
Department of Pharmacology, Meenakshi Medical College Hospital and Research Institute, Meenakshi Academy of Higher Education and Research, Kanchipuram, Tamil Nadu, India. Email: nithi_josan@yahoo.co.in
\end{abstract}

Received: 15 October 2019, Revised and Accepted: 12 November 2019

\section{ABSTRACT}

Objective: The objective of the study was to study the pattern of various types of cutaneous adverse drug reactions (CADRs) and its relation to therapeutic agents.

Methods: A retrospective study was carried out in the Department of Pharmacology, Meenakshi Medical College Hospital and Research Institute. Pharmacovigilance reports collected from 2017 to 2019 which were probable and certain by the WHO causality assessment were included in the study. Descriptive statistics were used. Values were expressed in numbers and percentage.

Results: Adverse drug reactions (ADRs) of 40 patients were selected based on the inclusion criteria, of which 22 were female (55\%) and 18 males $(45 \%)$. Patients aged $<50$ years had more incidence (77.5\%) of ADRs. Cutaneous manifestations contributed to major ADRs (67.5\%). CADRs were more common with antibiotics (55.5\%) followed by nonsteroidal anti-inflammatory drugs (14.6\%).

Conclusion: The most common therapeutic agent of CADRs were antibiotics (fluoroquinolones and cephalosporins) and the frequent cutaneous manifestation was urticaria.

Keywords: Cutaneous manifestations, Antibiotics, Adverse drug reactions.

(C) 2020 The Authors. Published by Innovare Academic Sciences Pvt Ltd. This is an open access article under the CC BY license (http://creativecommons. org/licenses/by/4. 0/) DOI: http://dx.doi.org/10.22159/ajpcr.2020.v13i1.36090

\section{INTRODUCTION}

Pharmacotherapy is aimed at relieving the sufferings, but sometimes they themselves can cause adverse drug reactions (ADRs). ADRs are noxious, unintended reactions occurring at normal doses. They are the important cause of increased health expenditure, morbidity, hospitalization, and even death [1]. Studies done in South Indian hospital on ADRs accounted for $0.7 \%$ of total admissions and $1.8 \%$ of total deaths [2]. Cutaneous ADRs (CADRs) are among the most frequent ADRs. Studies have found the incidence of CADRs in developed countries as $1-3 \%$, while in developing countries, it is higher between $2 \%$ and $5 \%$ [2-4]. Since there is an increase in the advent of newer drug molecules and newer treatment protocols, it is necessary to evaluate the CADRs [5]. Thus, active search is essential in identification of these CADRs, as both the patients and health-care professionals may tend to downplay the causal association between drug use and subsequent cutaneous manifestation. The purpose of this study was to assess the incidence and the pattern of CADRs and its causal association with drugs.

\section{METHODS}

A retrospective, observational study was conducted in the Department of Pharmacology, Meenakshi Medical College Hospital and Research Institute, over a period of 2 years from September 2017 to August 2019. Data regarding the patients were collected from suspected ADR reporting forms submitted to and assessed by the pharmacovigilance committee of this institution. ADRs classified as certain and probable by the WHO causality assessment scale were only included in this study. From the above-mentioned data, the pattern of CADRs and the drugs causing them, as well as the age- and gender-wise incidence of CADRs were analyzed. This study has been approved by the institutional ethics committee.
Statistical analysis

Descriptive statistics were used. Values were expressed in numbers and percentage.

\section{RESULTS}

Data of 40 patients were selected based on the inclusion criteria, of which 22 patients were female (55\%) and 18 were male (45\%). Patients aged $<50$ years had more incidence (77.5\%) of ADRs and patients aged $\geq 50$ had only $22.5 \%$ ADRs.

Among the ADRs, cutaneous manifestations contributed to major (67.5\%) type of ADRs followed by febrile illness (20\%), psychiatric manifestations, anaphylaxis, gastrointestinal manifestations, cardiovascular manifestations, and hematological alterations (each 2.5\%) as shown in Fig. 1.

The most common clinical type of cutaneous manifestation was urticaria (59\%), papules and macules (15\%), hyperpigmented lesions (7\%), fluid-filled lesions (7\%), peeling of skin (4\%), mucositis and cheilitis (4\%), and angioedema (4\%) as shown in Fig. 2.

The most common causative drugs causing these ADRs were antimicrobials followed by nonsteroidal anti-inflammatory drugs (NSAIDs). Urticaria was caused by ceftriaxone, ciprofloxacin, ondansetron, sodium valproate, amikacin, ketorolac, pantoprazole, ofloxacin, ornidazole, piperacillin+tazobactam, packed cells, iron preparation, isoniazid, and rifampicin. Papules and macules were resulted due to the use of drugs such as carbamazepine, cefotaxime, ciprofloxacin, nimesulide+paracetamol, and hyperpigmented lesions by ofloxacin, ornidazole, tinidazole, and racecadotril as shown in Table 1.

Among the antimicrobials fluoroquinolones, the third-generation cephalosporins and NSAIDs contributed to the maximum number of CADRs. 


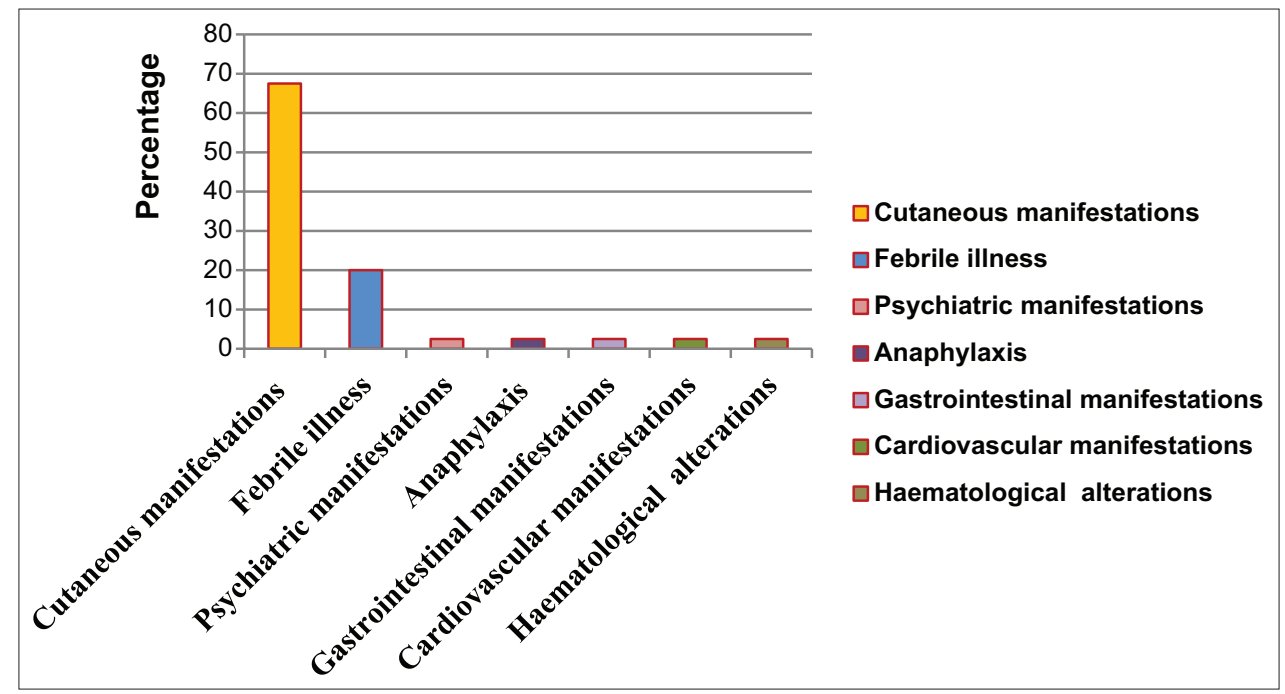

Fig. 1: Various patterns of adverse drug reactions reported in a tertiary care hospital

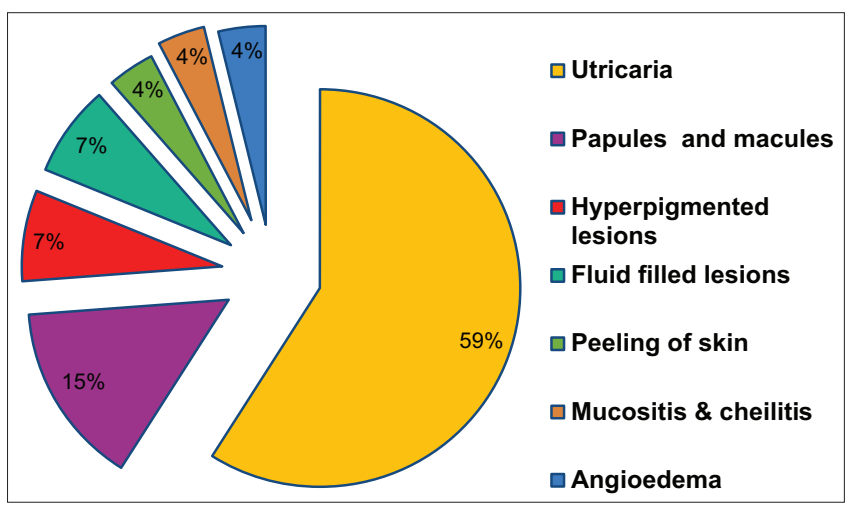

Fig. 2: Common clinical types of cutaneous adverse drug reactions

Table 1: Suspected drugs causing cutaneous manifestations

\begin{tabular}{|c|c|c|}
\hline $\begin{array}{l}\text { Cutaneous adverse } \\
\text { drug reactions }\end{array}$ & Percentage & Suspected drug \\
\hline Urticaria & 59 & $\begin{array}{l}\text { Ceftriaxone, ciprofloxacin, } \\
\text { ondansetron, sodium } \\
\text { valproate, amikacin, } \\
\text { ketorolac, pantoprazole, } \\
\text { ofloxacin, ornidazole, } \\
\text { piperacillin+tazobactam, } \\
\text { packed cells, iron } \\
\text { preparation, isoniazid, } \\
\text { rifampicin }\end{array}$ \\
\hline $\begin{array}{l}\text { Papules and } \\
\text { macules }\end{array}$ & 15 & $\begin{array}{l}\text { Carbamazepine, } \\
\text { cefotaxime, ciprofloxacin, } \\
\text { nimesulide+paracetamol }\end{array}$ \\
\hline $\begin{array}{l}\text { Hyperpigmented } \\
\text { lesions }\end{array}$ & 7 & $\begin{array}{l}\text { Ofloxacin, ornidazole, } \\
\text { tinidazole, racecadotril }\end{array}$ \\
\hline Fluid-filled lesions & 7 & Piroxicam, ofloxacin, cefixime \\
\hline Peeling of skin & 4 & Ofloxacin \\
\hline $\begin{array}{l}\text { Mucositis and } \\
\text { cheilitis }\end{array}$ & 4 & Methotrexate \\
\hline Angioedema & 4 & Paracetamol \\
\hline
\end{tabular}

\section{DISCUSSION}

In our study, the females had a slightly higher incidence of ADR than the males with a ratio of 1.2:1 which was similar to the other studies conducted [6-10]. In contrast, certain studies done by Patel and
Marfatia et al. showed male preponderance [11]. It was also found that the patients with the age group of $<50$ years had higher incidence of ADRs similar to the study done by Jena et al. [12], but the same did not comply with the reports of other studies $[4,5]$.

CADRs are the most common ADRs when compared with the prevalence of other ADRs [13]. CADRs pose a significant threat to the health of the patients. In the present study, urticaria was the most common CADR detected followed by macular and papular reactions, which was similar to the study done by Inbaraj et al [14]. The previous study by Al Raaie and Banodkar found drug-induced urticaria (35\%), whereas Pudukadan and Thappa found fixed drug eruption to be the most common CADR $[4,15]$. The WHO causality assessment of CADRs was probable in nature similar to the study done by Chatterjee et al. [16].

Among the drugs causing the CADRs, the most common drug groups involved were antimicrobials followed by NSAIDs in the present study. This is in concordance with other studies by Pudukadan and Thappa [4], Choon and Lai [17], Nandha et al. [18], and Qayoom et al. [9]. Al Raaie and Banodkar found NSAIDs to be the most common drug causing CADRs, whereas Noel et al. found antiepileptics to be the most common offending drug in their studies [15,19]. Different prescription patterns followed in various populations and regions can explain this variation.

Among the antimicrobials, fluoroquinolones were the most common drug involved followed by the third-generation cephalosporins. This was in conformity with these previous studies $[9,20]$. Ofloxacin was the leading cause of CADR in the present study. On the contrary, Amrinder et al. found ampicillin to be the most common antimicrobial, Saha et al. and Noel et al. found antiepileptics to be the most common offending drug to cause CADRs $[19,21,22]$. The difference in the pattern of antimicrobials between different studies could be due to the differences in the physician's preferences in using various antimicrobials.

\section{CONCLUSION}

There is no gold standard investigation available for diagnosing CADRs, but proper history relating to the duration of drug intake, reaction time, response of drug eruption to the withdrawal of the suspected drug and any history of similar reactions could be helpful in early identification of CADRs. It is prudent to watch them closely, as any amendment in pattern with older or newer agents will alert the health-care personnel. It is important to institute the appropriate prescription pattern and reporting of ADRs in every health-care center to improve the patient safety. 


\section{ACKNOWLEDGMENT}

We would like to extend our thanks to the Head of the Department, Dermatology and other Faculty of Dermatology Department, Meenakshi Medical College Hospital and Research Institute, Meenakshi Academy of Higher Education and Research, Enathur, Kanchipuram for reporting ADRs and helping us in this study.

\section{AUTHORS' CONTRIBUTIONS}

Nithya Panneerselvam: Concept, design, data acquisition and analysis and manuscript preparation.

Parimala Kadhirvelu: Concept, design, manuscript editing and manuscript review.

\section{CONFLICTS OF INTEREST}

None declared.

\section{REFERENCES}

1. Nerurkar RP, Nadkar MY, Bichile SK. Need for monitoring adverse drug reactions. J Assoc Physicians India 1998;46:673-4

2. Ramesh M, Pandit J, Parthasarathi G. Adverse drug reactions in a South Indian hospital their severity and cost involved. Pharmacoepidemiol Drug Saf 2003;12:687-92.

3. Bigby M. Rates of cutaneous reactions to drugs. Arch Dermatol 2001;137:765-70.

4. Pudukadan D, Thappa DM. Adverse cutaneous drug reactions: Clinical pattern and causative agents in a tertiary care center in South India. Indian J Dermatol Venereol Leprol 2004;70:20-4.

5. Sharma VK, Sethuraman G, Kumar B. Cutaneous adverse drug reactions: Clinical pattern and causative agents a 6 year series from Chandigarh, India. J Postgrad Med 2001;47:95-9.

6. Bem JL, Breckenridge AM, Mann RD, Rawlins MD. Review of yellow cards (1986): Report to the committee on the safety of medicines. Br J Clin Pharmacol 1988;26:679-89.

7. Moore N, Noblet C, Kreft-Jais C, Lagier G, Ollagnier M, Imbs JL. French pharmacovigilance database system: Examples of utilization. Therapie 1995;50:557-62.

8. Faich GA, Knapp D, Dreis M, Turner W. National adverse drug reaction surveillance: 1985. JAMA 1987;257:2068-70.

9. Qayoom S, Bisati S, Manzoor S, Sameem F, Khan K. Adverse cutaneous drug reactions a clinico-demographic study in a tertiary care teaching hospital of the Kashmir Valley, India. Arch Iran Med 2015;18:228-33

10. Siddiqui S, Baig MM, Jaffer S, Ansari SF. Study on prevalence of adverse drug reactions in patients suffering from tuberculosis in a tertiary care hospital. Int J Pharm Pharm Sci 2016;8:375-7.

11. Patel RM, Marfatia YS. Clinical study of cutaneous drug eruption in 200 patients. Indian J Dermatol Venereol Leprol 2008;74:74-80.

12. Jena SS, Jena M, Patro N, Mishra S, Panda M, Dash M. Patterns of prescription and ADR monitoring of drugs in the management of neuropathic pain in a tertiary care teaching hospital. Int J Pharm Pharm Sci 2014;6:246-51

13. Naldi L, Conforti A, Venegoni M, Troncon MG, Caputi A, Ghiotto E, et al. Cutaneous reactions to drugs. An analysis of spontaneous reports in four Italian regions. Br J Clin Pharmacol 1999;48:839-46.

14. Inbaraj SD, Muniappan M, Muthiah NS, Arul A, Glory J, Rahman F. Pharmacovigilance of cutaneous drug reactions in outpatients of dermatology department at a tertiary care hospital. J Clin Diagn Res 2012;6:1688-91.

15. Al Raaie F, Banodkar DD. Cutaneous adverse reactions in Oman. Oman Med J 2008;23:21-7

16. Chatterjee S, Ghosh AP, Barbhuiya J, Dey SK. Adverse cutaneous drug reactions: A one-year survey at a dermatology outpatient clinic of a tertiary care hospital. Indian J Pharmacol 2006;38:429-31

17. Choon S, Lai N. An epidemiological and clinical analysis of cutaneous adverse drug reactions seen in a tertiary hospital in Johor, Malaysia. Indian J Dermatol Venereol Leprol 2012;78:734-9.

18. Nandha R, Gupta A, Hashmi A. Cutaneous adverse drug reactions in a tertiary care teaching hospital: A North Indian perspective. Int J Appl Basic Med Res 2011;1:50-3.

19. Noel MV, Sushma M, Guido S. Cutaneous adverse drug reactions in hospitalized patients in a tertiary care centre. Indian J Pharmacol 2004;36:292-5.

20. Vijeyakumar TM, Dhanraju MD. Description of adverse drug reactions in a multispeciality teaching hospital. Int J Integr Med 2013;1:1-6.

21. Amrinder R, Kaur I, Singh J, Kaur T. Monitoring of cutaneous adverse drug reactions in a tertiary care hospital. J Pharmacovigil 2016;4:207.

22. Saha A, Das NK, Hazra A, Gharami RC, Chowdhury SN, Datta PK. Cutaneous adverse drug reaction profile in a tertiary care out patient setting in Eastern India. Indian J Pharmacol 2012;44:792-7. 